I I S

IBS WORKING PAPER 04/2018

MAY 2018

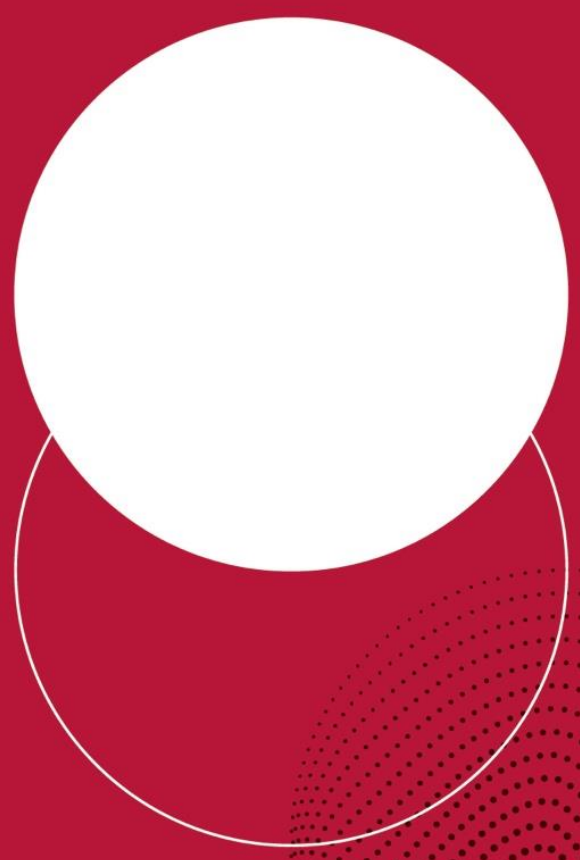

\title{
WORKING TIME FLEXIBILITY AND \\ PARENTAL 'QUALITY TIME' SPENT WITH CHILDREN
}

Iga Magda

Roma Keister

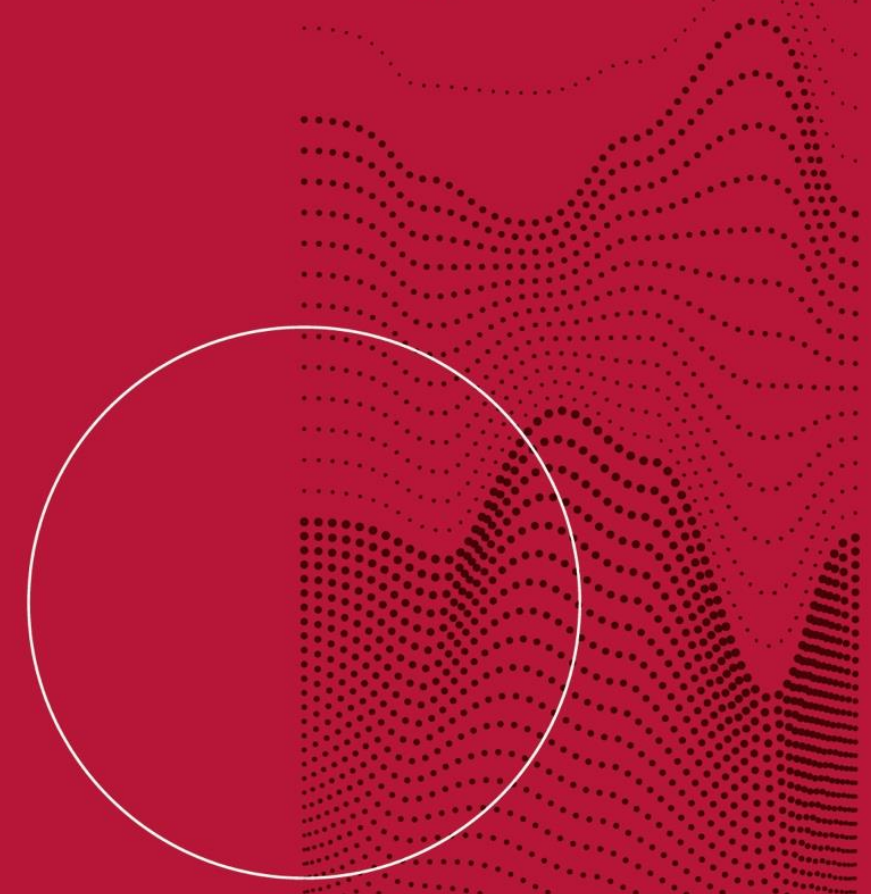




\title{
WORKING TIME FLEXIBILITY AND PARENTAL 'QUALITY TIME' SPENT WITH CHILDREN`
}

Iga Magda*

Roma Keister*

\begin{abstract}
The aim of our paper is to analyse the relationship between working time flexibility and parental time devoted to children. Using data from a large panel survey of Polish households carried out in 2013 and 2014 (Determinants of Educational Decisions Household Panel Survey, UDE) we investigate whether and how various dimensions of working time flexibility affect the amount of time parents spend with their children reading, playing or teaching them new things. We account for employment status of parents, their socio-economic status and social and cultural norms they share. Our results show that employment status of parents and their working time arrangements are not statistically significant for the amount of parental 'quality time' devoted to children. We show that these are parental human and cultural capital and their values that are primary factors determining the amount of parental time investments.
\end{abstract}

Keywords: working time flexibility, parental time investments, child care, 'quality time with children' JEL: J13, J22, J81

\footnotetext{
- We thank the participants of the PAA 2017 conference in Chicago and WIEM 2017 conference in Warsaw for their insightful comments. This paper uses Determinants of Educational Decisions Household Panel Survey data conducted by the Educational Research Institute within the project Research on the quality and effectiveness of education and institutionalization of research facilities co-financed by the European Social Fund under the Human Capital Operational Programme. The usual disclaimers apply. All errors are ours.

- Corresponding author, Institute for Structural Research (IBS) \& Warsaw School of Economics, iga.magda@ibs.org.pl.

* Institute for Structural Research (IBS) \& Warsaw School of Economics, roma.keister@ibs.org.pl.
} 


\section{Introduction}

The time parents spend with their children, especially "quality time" spent on educational activities or play, rather than caring duties, significantly affects children's' skill formation and their future life outcomes, employment opportunities and incomes. Its role has increased over the past years, with parents spending more 'quality time' with their children than they did in the past decades (Sayer, Bianchi and Robinson 2004 for the US, Dotti Sani and Treas, 2016 for European countries).

This importance of parental time devoted to children for child outcomes has long been recognized in the literature, both its social and economic strand. During childhood, family influence and environment significantly affect skill formation and adult incomes, and parenting and parental time play a crucial role (Dotti Sani and Treas 2016; Francesconi and Heckman 2016, Carneiro and Ginja 2015), which can even be more important than formal education (Fiorini and Keane 2014). When measuring parental time investments, much of the existing recent evidence is based on maternal employment or hours worked, taken as proxies for the time mother does not spend with their children on care activities (Francesconi et al. 2016). However, not all the time mothers do not spend working is actually allocated to their children and the "productivity" of this time varies. Moreover, this "productivity" may only weakly be correlated with other parental variables, such as their employment decisions and occupation (Gayle, Golan, and Soytas 2015).

The amount of parental time devoted to children differs among families depending on their socio-economic status. Primarily, parental skills impact child investments (Aizer and Cunha 2012, Carneiro and Ginja 2015) and intensive parenting is more likely among the well-educated parents (Sayer et al. 2004, Dotti Sani and Treas 2016). There are several explanations for this, for instance the fact that that better educated women delay childbearing, are more likely to be married, have substantially better-educated spouses and higher family income (Carneiro et al. 2013), but also increased bargaining power (Bruins 2017). Also employment (vs inactivity) differentiates parents in their use of time spent on caring activities (Bianchi 2000). Families with less educated mothers are also more likely to lower time invested in children as a reaction to a drop in income (Carneiro and Ginja 2015). Much less is known about how parental time with children is shaped by within household time constraints related to both mother's and father's job (in)flexibility.

The aim of our paper is to analyse the relationship between parental employment, its level of working time flexibility and the amount of parental time spent with children. Using data from a large panel survey of Polish households carried out in 2013 and 2014 (Determinants of Educational Decisions Household Panel Survey, UDE) we investigate how the mothers' and fathers' employment status and their working time arrangements influence the amount of time spent on educational activities with their children. We answer three sets of questions: (1) What are parental characteristics associated with parental time investments into children? (2) Do working parents spend less educational time with their children compared to non-working parents? (3) Are these relationships impacted by the availability of flexible scheduling at work? Thus, we merge two strands of literature: on investments in child development and on working time flexibility and caring strategies families choose depending on their employment arrangements. We also include in our analysis information on family and work attitudes and values, since child rearing remains subject to strong social norms. From an economic perspective, we also add to the growing literature on earnings inequalities and their determinants, as family is the most important factor in accounting for the inequality of permanent earnings over the life cycle, more important than neighbourhood or schools (Bingley et al. 2016). 
The analysis is carried out for Poland, which is an interesting case to study for two major reasons. First, countries outside Western Europe, US or Canada have been under-researched so far with respect to parental investments into children (Dotti Sani and Treas 2016). Secondly Poland, as other Central and Eastern European countries, underwent an important transition and structural change both on its labour market and in its family policy environment (Kotowska et al. 2008, Razzu 2016). Currently, it represents a tradition of relatively high female employment rates (among prime aged women), a system of relative generous maternal/parental leaves combined with difficulties with childcare access and a low share of part time employment and long female working hours. Polish fertility rates are among the lowest in the EU, reflecting mainly work- family conflict (Matysiak, WęziakBiałowolska 2016).

The paper is structured as follows. Section 2 focuses on the relationship between working time flexibility and parental time devoted to children. Section 3 briefly describes institutional background in Poland with respect to the family policy. Section 4 provides a comprehensive description of data and methodology used. Section 5 examines the relationship between intensity of parenting and various households' characteristics, and working time flexibility of parents. Section 6 concludes.

\section{Labour market position, flexible working arrangements and parental time spent with children}

Flexible working time arrangements refer to a set of measures and practices that can serve the employee to better combine work and family lives, and the employer to better organise production or service delivery. These include reduced hours, flexitime possibilities (e.g. part-time work, flexible start and finishing times) and more advanced options, such as (partial) telework from home, shift and weekend work. However, while some of these options can be beneficial for both employers and employees (or at least neutral), some of the existing working time arrangements are more likely to increase flexibility for the employers, but not necessarily for workers, for whom such a flexibility worsens the prospects of planning everyday life arrangements. For instance, this is the case of flexible scheduling, if it means having to work at short notice. Other solutions, like the possibility to take an hour off during the day, or "right to ask" for a variety of work schedule accommodations, are more likely to benefit workers, but make it more difficult for the employer to plan the schedules (decreasing thus the likelihood of offering these flexible arrangements to workers, if these are at their discretion). We expect that those flexible work options that increase workers' flexibility, allow them to better manage their working time and adjust it to their needs, increase the probability that these parents will spend more time with their children, all other things equal. Parents who report working time flexibility in those dimensions that limit their control over their working time, will likely be spending less time on educational activities with their children. There is evidence that flexible work options may not be granted evenly to different groups of workers. For instance, high-status men seeking flexible schedules in order to advance their careers may be more likely to have their requests accepted than women in similar positions (Brescoll et al. 2016, Golden 2001). Access to flexible working arrangements is not universal across job categories (or their sectoral affiliation) either, and this uneven access to working time flexibility may actual go along the line of employee-employer flexibility. High skilled workers, despite increasingly longer working times, are likely to enjoy more control over their working time, whereas many lower skilled workers, in particular in the service sector, have to accept unstable work shifts offered to them in highly competitive labour markets (Kalleberg et al. 2000, Bidwell et al. 2013). 
Few studies have touched upon the relationship between working time arrangements and parental time investments into children. Focusing mostly on flexible working hours and using cross-sectional data for Australia, Baxter (2010) showed that these are not statistically significant for parental time inputs in children. Job flexibility associated with the location of work (flexplace) has been shown to positively affect the amount of time Canadian mothers spend with children (Craig and Powell 2012), but at the same time proved insignificant for fathers. Another strand of research focuses on the long working hours of parents and their relationship with the parental time investments. Baxter (2010) found negative effects of long working hours for the amount of time parents spend with children, while Hoherz (2016) likewise found negative association between those two but only for parents with a lower income. Moreover, this effect seems particularly important for fathers, and not for mothers, with mothers generally devoting significantly more time to children (Craig et al. 2014, Monna and Gauthier 2008). Likewise, both mothers and fathers working non-standard hours spent more time in paid work and less time with their children than parents who worked standard hours (Craig 2012). Same study argued that flexibility related to the place of work proved to be important for the time spent with children for mothers, and to lesser extent for fathers. Importantly, at an international level, the link between long work hours and child care time is further blurred by influences from distinct cultural models of parenting, as documented by Sayer and Gornick (2011), who found find substantial variation in child care time across countries with similar work hour cultures and work/family policies (e.g. France and Norway) and close similarity across countries with dissimilar work hour cultures and family policies (e.g. Norway and Canada). The importance of the institutional context was emphasized also by Roeters (2011).

We add to the existing literature in four ways. First, we provide a more in depth analysis of the link between parent's employment status and their parental quality time devoted children, accounting also for parental socioeconomic background. Second, our analysis of the association of working time flexibility and parental time spent with children includes several dimensions of such flexibility (and lack thereof). Third, as opposed to most of the existing studies, we are able to focus solely on "quality time" spent with children, which includes educational and playing activities, as distinguished from time spent on care. Finally, drawing on the importance of the national context, our analysis covers a country with an institutional regime different from the ones studies in the literature so far, which we discuss in more detail in the next section.

\section{Institutional background}

As documented above, the intensity of parental activities with children may be shaped not only by the parents' characteristics but also norms, values and institutions (such as family and labour market policy setting) prevalent in the country. In this respect Poland represents a Central European country, with "embedded neoliberalism' (Bohle and Greskovits, 2007). From a family policy perspective, it has relatively long paid maternity leaves and insufficient childcare coverage, in particular for the youngest children below 3 years of age, where it is rather scarce. Also cultural factors play a role, with Poland distinguishing itself with the second highest share of respondents (almost 50\%) declaring mothers with children under school age should stay at home (ISSP 2012 data). Researchers also emphasize a refamilialist direction of family policies in post-communist countries (Saxonberg and Szelewa 2007, Javornik 2014). Thus, tensions between motherhood and employment arise and there are little incentives for fathers to participate in child care duties (Plomień 2009). 
From a labour market perspective, parenthood is usually associated with lower labour supply for women, and slightly higher labour supply for men, but in Poland these differences are rather small. The employment rate of mothers stands at a relatively high level $(67,6 \%$ in 2014 , comparable with Germany (68\%) and above UK or US levels of 67 and $65,7 \%$ ), though a gap arises in employment rates of mothers with the youngest children. Likewise, the motherhood pay gap in Poland is rather modest, suggesting low pay differences among mothers and nonmothers (Cukrowska - Torzewska \& Lovasz, 2017). As other CEE countries, Poland distinguishes itself with a low share of part time workers, particularly among women (12\%, compared to over $30 \%$ in most Western European countries, Razzu 2016).

Despite relatively high and intensive labour market participation, Polish women spend also a lot of time on physical care and supervision of children: on average 22 minutes a day, slightly more than women in most other European countries (HETUS data, Eurostat). A larger difference concerns time spent on activities such as teaching, reading, and talking with a child, where they declare twice more time spent compared to women in other EU countries. Polish men also declare a relatively high number of minutes spent on children's education each day (but not on physical care for children, where they fall at EU average).

Another particularity of the Polish labour market setting - which might impact working time flexibility, and thus work life balance and time investments into children we study - is the substantial decline in the share of openended employment and the accompanying gradual growth in temporary employment, both observed in Poland since early 2000s (Broughton et al. 2016). It is not obvious - a priori - whether these mean more or less working time flexibility allowing spending more/less time with family. Yet, this increase in non-standard employment partly meant growing precariousness (lack of employment protection, limited social security coverage). Thus we expect it to impact the link between type of job held and time investments into children and account for the type of job held in our analysis.

Finally, job quality and flexibility patterns largely stem from institutional regimes, and related employment policies, and some substantial similarities between countries of similar institutional regimes can be observed (Holman 2013). In this respect, the patterns of working time flexibility and job quality of Polish workers resemble those of other workers in the CEE countries (EWCS 2015). The mean number of hours worked is average from the European perspective, but there is large heterogeneity among workers, suggesting many of them work either very long, or relatively short hours.

\section{Data \& methods}

We use the 2013 wave of UDE, - Determinants of Educational Decisions, a large panel survey of Polish households (approx. 24000 households, 64000 individuals) gathering information on human capital formation in an intergenerational perspective. It combines a rich set of information on children and their parents, such as their demographic and labour market characteristics, with a set of detailed information on caring and educational activities. It covers also labour market, family biography and migration retrospective surveys.

As we are interested mainly parents' educational activities with children, our final sample consists only of households with at least one child. We also exclude various types of extended families from our sample, since the presence of other family members in the household would likely affect the amount of time spent with children on educational activities. For the same reason, we likewise restrict our sample to households with children without any kind of disability. Our final sample consists of almost 6700 households and 24000 individuals of which 12 
625 are parents, units of our study. Most important demographic characteristics of the sample are presented in the Table 1.

Table 1. Demographic characteristics of the sample and measures of the parenting intensity

\begin{tabular}{|c|c|c|}
\hline & $\%$ & (SE) \\
\hline \multicolumn{3}{|l|}{ Labour market status } \\
\hline open-ended contract $(n=6,907)$ & 65.9 & $(-0.7)$ \\
\hline fixed-term contract $(n=1,405)$ & 12.5 & $(-0.4)$ \\
\hline unemployed $(n=1,489)$ & 12.9 & $(-0.5)$ \\
\hline inactive $(n=873)$ & 8.8 & $(-0.4)$ \\
\hline \multicolumn{3}{|l|}{ Educational attainment } \\
\hline primary $(n=924)$ & 8.1 & $(-0.4)$ \\
\hline basic vocational $(n=3,262)$ & 32.6 & $(-0.7)$ \\
\hline general secondary $(n=1,239)$ & 9.8 & $(-0.4)$ \\
\hline vocational secondary and post-secondary $(n=2,612)$ & 22.8 & $(-0.6)$ \\
\hline tertiary $(n=3,157)$ & 26.6 & $(-0.6)$ \\
\hline \multicolumn{3}{|l|}{ Degree of urbanization of place of residence } \\
\hline rural areas $(\mathrm{n}=4,313)$ & 43.6 & $(-0.7)$ \\
\hline town with less than 50k inhabitants $(n=2,876)$ & 24.1 & $(-0.6)$ \\
\hline town with 50k - 200k inhabitants $(n=1,828)$ & 14.1 & $(-0.4)$ \\
\hline town with more than 200k inhabitants $(n=2,177)$ & 18.3 & $(-0.5)$ \\
\hline \multicolumn{3}{|l|}{ Presence of children aged less than 3 in the household } \\
\hline $0(\mathrm{n}=7,479)$ & 68.4 & $(-0.6)$ \\
\hline $1(n=3,715)$ & 31.6 & $(-0.6)$ \\
\hline \multicolumn{3}{|l|}{ Number of children aged below 15 in the household } \\
\hline $0(n=5,129)$ & 41.3 & $(-0.7)$ \\
\hline $1(n=4,520)$ & 42 & $(-0.7)$ \\
\hline 2 or more $(n=1,545)$ & 16.7 & $(-0.5)$ \\
\hline \multicolumn{3}{|c|}{ Number of books in parents' family homes when they were 10} \\
\hline less than 10 books $(n=1,967)$ & 20.4 & $(-0.6)$ \\
\hline $11-25$ books $(n=2,875)$ & 27.2 & $(-0.6)$ \\
\hline $26-100$ books $(n=3,860)$ & 33.8 & $(-0.6)$ \\
\hline $101-200$ books $(n=1,261)$ & 11 & $(-0.4)$ \\
\hline more than 200 (n=883) & 7.5 & $(-0.3)$ \\
\hline \multicolumn{3}{|l|}{ The importance of family values } \\
\hline not important $(\mathrm{n}=1,804)$ & 17.2 & $(-0.5)$ \\
\hline important $(\mathrm{n}=9,390)$ & 82.8 & $(-0.5)$ \\
\hline \multicolumn{3}{|l|}{ Intensity of educational activities with children aged 1-7 } \\
\hline low $(n=2,812)$ & 43.1 & $(-0.9)$ \\
\hline $\operatorname{high}(n=3,521)$ & 56.9 & $(-0.9)$ \\
\hline \multicolumn{3}{|l|}{ Intensity of educational activities with children aged 8-14 } \\
\hline $0(n=3,231)$ & 51.6 & $(-0.9)$ \\
\hline $1(n=3,302)$ & 48.4 & $(-0.9)$ \\
\hline
\end{tabular}

Source: own calculations based on UDE data. 
Our variable of interest measures the incidence of spending time by parents on various educational activities with children (questions include activities such as reading, playing with them or teaching them new things) using a two-level scale, and is estimated separately for children of ages 1-7 and 8-14 (as types of educational activities are different for these two groups). In particular, the head of the household is asked how often household members perform given educational activity with a particular child, and may choose between four answers ranging from 1to4, where 1 means "never or almost never" and 4 stands for "every day or almost every day". Since those questions are asked only at the household level, we are not able to distinguish between mother's and father's time spent with children. For each household we calculate the average of those scores - the higher the score, the more time parents spend with children on educational activities. Next, using these household-specific means of parental educational intensity ${ }^{2}$, we ascribed 0 to households which scored below the sample average, and 1 to households which scored above this threshold. We additionally created a three-level scale of parenting intensity and run robustness checks applying this measure (Table 6 in appendix).

In order to analyse the determinants of educational investments into children we estimate a set of logistic regression models. In the first one we account for parent's labour market position including the type of employment contract, their educational attainment, degree of urbanisation of the place of residence, age of parents, information on the number of children in the household and a dummy on the presence of children aged less than 3 in the household. Next, we try to account for unobservable characteristics of parents which may influence the intensity of parenting, and thus likely confound our estimates. To this aim, we include a set of variables which proxy intergenerational transmission of norms, values and attitudes (Chiswick 1988). In particular, in the second model we add information on the number of books in parents' family homes when they were 10. In the third model we further add a variable describing the importance of family values in parents' family homes. Books at home provide a powerful proxy for the educational, social and economic background in most countries (Lynch and O'Riordan 1998, Evans et al. 2010), and books at home are the single most important predictor of e.g. student performance, even surpassing parental education (Wößmann 2003, 2004). Cultural norms, reflected in the importance of family values may also influence childcare and parenting decisions (Amatea et al. 1996, Cinamon and Rich 2002, Gornick and Meyers 2003). All these models are run separately for households with children aged 1-7 and those with children aged 8-15. Standard errors are clustered at the household level since our left-hand side variable is fixed within the household.

The second part of our analysis is devoted to the main question we ask, whether higher working time flexibility is associated with higher parental time investments into children, all other things equal. Our data lacks information on working time flexibility of respondents or their exact number of hours worked. Therefore, we use the European Working Conditions Survey (EWCS) data to calculate a set of working time flexibility measures associated with

\footnotetext{
${ }^{1}$ Since we excluded various types of extended households, it is likely that these are parents who perform those educational activities with children, and not other household members. One might be concerned that our parenting measure is biased upwards if children aged 15 years and more are present in the household. However, the presence of children of this age turned out either statistically insignificant or negatively related to parenting intensity.

${ }^{2}$ For the purposes of this paper and its clarity, we use term "parenting" for a description of educational activities intensity. of course, in real life, parenting is a much broader concept and our assumption is a simplification.
} 
different jobs and occupations. We follow the approach of Eurofound in calculating the particular working time flexibility indices, and differentiate between four dimensions of working time flexibility (Eurofound 2016) ${ }^{3}$.

\section{Results}

\subsection{Parental employment status, socio-economic background, and time investments into children}

In line with the literature, we expect the working parents to spend more time with their children than non-working ones, despite time budget restrictions. This is confirmed only partially: working parents are more likely to invest quality time in children only if compared to parents who are unemployed (Table 2, where we regress the parental intensity against dummies describing parents' labor market position). The difference is insignificant with respect to inactive parents (although it also shows a parenting gap among the inactive parents). The results are similar for parents of younger and older children.

Yet, further analyses (Table 3) show that the link between parental employment status and parenting intensity is due to other factors, not the parents labor market position per se. In particular, once we add to our model basic individual and household characteristics (Model 1, columns [1a] and [1b]), such as age, education, degree of urbanization, and the number of children, the parental employment status becomes insignificant. It is the educational status that turns out to matter for the parenting intensity - parents with higher levels of education are much more likely to report intensive parenting4.The link is strong - the probability of spending time on educational activities is greater among tertiary educated parents compared to parents with primary educational attainment (by 0.17 for parents of younger children and by 0.285 for older children). These are also parental background and the values and attitudes shared by families that matter for parenting intensity (columns [2a], [2b], [3a] and [3b]). Both measures are statistically significant: parents, who had more books at home and those who declare family values were important in their family homes are more likely to report more intensive parenting, both among youngest and older children. Inclusion of the information on growing with books weakened the impact of education, pointing to the role of intergenerational transmission of education and the strong link between educational attainment and one's socioeconomic background (Fergusson et al. 2008, van Doom et al. 2011).

\footnotetext{
${ }^{3}$ These four dimensions include: duration (working long hours, working long days), atypical working time (the incidence of night work, Saturday work, Sunday work, the incidence of shift work), working time arrangements (the flexibility of scheduling, having to work at short notice), flexibility (the possibility of taking the hour-off from work, and having to work free-time). Job flexibility measures are described in more detail in the Appendix.

${ }^{4}$ Education and labour market position are also intertwined with the parents and households' income levels, thus one could suspect that better educated parents spend more time with their children simply because they can afford it. Yet, adding information on the households' income position does not alter the results and does not impact the intensity and incidence of educational activities with children. Detailed results are available upon request.
} 
Table 2. Marginal effects of intensive parenting probability

\begin{tabular}{|c|c|c|}
\hline & $\begin{array}{c}\text { parenting, children aged 1-7 } \\
\text { (0-low, 1-high) }\end{array}$ & $\begin{array}{l}\text { parenting, children aged 8-15 } \\
\text { (0-low, 1-high) }\end{array}$ \\
\hline \multicolumn{3}{|l|}{ ref. employed - open-ended contract } \\
\hline \multirow{2}{*}{ employed - fixed term contract } & -0.025 & -0.041 \\
\hline & $(-0.081-0.031)$ & $(-0.097-0.015)$ \\
\hline \multirow{2}{*}{ unemployed } & $-0.069 * \star \star$ & $-0.072^{\star \star \star}$ \\
\hline & $(-0.121--0.017)$ & $(-0.126--0.018)$ \\
\hline \multirow{2}{*}{ inactive } & -0.054 & -0.035 \\
\hline & $(-0.119-0.012)$ & $(-0.099-0.028)$ \\
\hline
\end{tabular}

Confidence intervals (95\%) in parentheses, ${ }^{* *} p<0.01,{ }^{* *} p<0.05,{ }^{*} p<0.1$

Source: own estimations based on UDE data.

There is no strong link between the size of place pf residence and time parents spend with children on educational activities. The gap concerns only parents of older children living in largest cities who are slightly more likely to spend quality time with their children compared to inhabitants of smaller towns and rural areas. Finally, children's' composition in the household matters as well: parents of children aged less than 3 are less likely to invest in time spent on educational activities with his/her siblings aged 3-6 (but this does not hold for older siblings). The effect in question is quite strong - the presence of children aged less than 3 in the household is associated with the decrease of high intensity parenting probability from 0.67 to 0.49 , all other variables at means. Also presence of children aged $7+$ in the household decreases parenting intensity towards youngest children, but the size of this effect is significantly smaller (marginal effect of -0.041).

Table 3. Marginal effects of intensive parenting probability, all other explanatory variables at their means

\begin{tabular}{|c|c|c|c|c|c|c|}
\hline & $\begin{array}{l}\text { Model } 1 \\
\text { [1a] }\end{array}$ & $\begin{array}{c}\text { Model } 2 \\
{[2 \mathrm{a}]}\end{array}$ & $\begin{array}{c}\text { Model } 3 \\
\text { [3a] }\end{array}$ & $\begin{array}{l}\text { Model } 4 \\
{[1 b]}\end{array}$ & $\begin{array}{l}\text { Model } 5 \\
{[2 \mathrm{~b}]}\end{array}$ & $\begin{array}{c}\text { Model } 6 \\
{[3 b]}\end{array}$ \\
\hline & \multicolumn{3}{|c|}{ parenting, children aged 1-7 (0-low, 1-high) } & \multicolumn{3}{|c|}{ parenting, children aged 8-15 (0-low, 1-high) } \\
\hline \multicolumn{7}{|c|}{ ref. employed: open-ended contract } \\
\hline \multirow{2}{*}{$\begin{array}{r}\text { employed: fixed-term } \\
\text { contract }\end{array}$} & -0.018 & -0.023 & -0.022 & -0.026 & -0.016 & -0.011 \\
\hline & $(-0.074-0.038)$ & $(-0.081-0.034)$ & $(-0.080-0.035)$ & $(-0.084-0.032)$ & $(-0.079-0.046)$ & $(-0.074-0.052)$ \\
\hline \multirow{2}{*}{ unemployed } & -0.033 & -0.032 & -0.031 & -0.024 & -0.021 & -0.018 \\
\hline & $(-0.088-0.022)$ & $(-0.090-0.027)$ & $(-0.089-0.027)$ & $(-0.080-0.032)$ & $(-0.079-0.036)$ & $(-0.075-0.040)$ \\
\hline \multirow[b]{2}{*}{ inactive } & -0.011 & -0.015 & -0.012 & 0.018 & 0.007 & 0.009 \\
\hline & $(-0.075-0.054)$ & $(-0.082-0.053)$ & $(-0.080-0.056)$ & $(-0.046-0.081)$ & $(-0.060-0.073)$ & $(-0.058-0.076)$ \\
\hline \multicolumn{7}{|l|}{ ref. primary education } \\
\hline \multirow{2}{*}{ basic vocational } & $0.084^{\star \star}$ & $0.076^{\star}$ & 0.073 & 0.037 & 0.010 & 0.006 \\
\hline & $(0.004-0.163)$ & $(-0.011-0.164)$ & $(-0.015-0.161)$ & $(-0.028-0.102)$ & $(-0.063-0.083)$ & $(-0.067-0.078)$ \\
\hline \multirow{2}{*}{ general secondary } & $0.183^{\star \star \star}$ & $0.158 \star \star \star$ & $0.156^{\star \star \star}$ & $0.105^{\star \star}$ & 0.050 & 0.046 \\
\hline & $(0.093-0.272)$ & $(0.061-0.256)$ & $(0.058-0.253)$ & $(0.024-0.187)$ & $(-0.040-0.140)$ & $(-0.043-0.136)$ \\
\hline \multirow{2}{*}{$\begin{array}{r}\text { vocational secondary and } \\
\text { post-secondary }\end{array}$} & $0.158^{\star \star \star}$ & $0.132^{\star \star \star}$ & $0.131 \star \star \star$ & $0.126^{\star \star \star}$ & $0.066^{\star}$ & 0.062 \\
\hline & $(0.077-0.240)$ & $(0.042-0.222)$ & $(0.041-0.221)$ & $(0.055-0.196)$ & $(-0.012-0.145)$ & $(-0.017-0.140)$ \\
\hline \multirow{2}{*}{ tertiary } & $0.172^{\star \star \star}$ & $0.120 * \star$ & 0.116 *ᄎ & $0.285^{\star \star \star}$ & $0.204^{\star \star \star}$ & $0.199 \star \star \star$ \\
\hline & $(0.089-0.255)$ & $(0.027-0.213)$ & $(0.023-0.209)$ & $(0.209-0.361)$ & $(0.118-0.290)$ & $(0.113-0.285)$ \\
\hline
\end{tabular}




\begin{tabular}{|c|c|c|c|c|c|c|}
\hline \multicolumn{7}{|l|}{ ref. rural areas } \\
\hline \multirow{2}{*}{$\begin{array}{r}\text { town with less than } 50 \mathrm{k} \\
\text { inhabitants }\end{array}$} & $0.072^{\star \star}$ & 0.046 & 0.051 & $0.075^{\star \star}$ & 0.048 & 0.050 \\
\hline & $(0.011-0.133)$ & $(-0.018-0.110)$ & $(-0.013-0.114)$ & $(0.017-0.133)$ & $(-0.013-0.110)$ & $(-0.011-0.112)$ \\
\hline \multirow{2}{*}{$\begin{array}{r}\text { town with } 50 \mathrm{k}-200 \mathrm{k} \\
\text { inhabitants }\end{array}$} & 0.014 & -0.022 & -0.018 & $0.084^{\star \star}$ & 0.045 & 0.051 \\
\hline & $(-0.055-0.082)$ & $(-0.092-0.048)$ & $(-0.089-0.052)$ & $(0.017-0.150)$ & $(-0.025-0.115)$ & $(-0.018-0.121)$ \\
\hline \multirow{2}{*}{$\begin{array}{l}\text { town with more than } \\
200 \mathrm{k} \text { inhabitants }\end{array}$} & $0.074^{\star \star}$ & 0.053 & 0.059 & $0.108^{\star \star \star}$ & $0.072^{\star}$ & $0.082^{\star \star}$ \\
\hline & $(0.006-0.141)$ & $(-0.018-0.124)$ & $(-0.012-0.131)$ & $(0.038-0.178)$ & $(-0.003-0.147)$ & $(0.005-0.158)$ \\
\hline \multirow{2}{*}{$\begin{array}{l}\text { children aged }<3 \text { in the } \\
\text { household ( } 0 \text { no, } 1 \text { yes) }\end{array}$} & 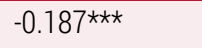 & $-0.185^{\star \star \star}$ & $-0.185^{\star \star \star}$ & 0.036 & 0.039 & 0.044 \\
\hline & $\begin{array}{l}(-0.238- \\
-0.137)\end{array}$ & $\begin{array}{l}(-0.236- \\
-0.134)\end{array}$ & $\begin{array}{l}(-0.236- \\
-0.133)\end{array}$ & $(-0.034-0.106)$ & $(-0.034-0.112)$ & $(-0.029-0.117)$ \\
\hline \multirow{2}{*}{$\begin{array}{l}\text { number of children } \\
\text { aged }>7 \text { in the household }\end{array}$} & $-0.041^{\star \star}$ & $-0.041^{\star \star}$ & $-0.041^{\star \star}$ & & & \\
\hline & $\begin{array}{l}(-0.077- \\
-0.005)\end{array}$ & $\begin{array}{l}(-0.078- \\
-0.003)\end{array}$ & $\begin{array}{l}(-0.079- \\
-0.003)\end{array}$ & & & \\
\hline \multirow[b]{2}{*}{ age of parents } & 0.001 & 0.002 & 0.002 & $-0.004^{\star \star}$ & $-0.004^{\star \star}$ & $-0.004^{\star \star}$ \\
\hline & $(-0.003-0.005)$ & $(-0.002-0.006)$ & $(-0.002-0.006)$ & $\begin{array}{l}(-0.008- \\
-0.000)\end{array}$ & $\begin{array}{l}(-0.008- \\
-0.000)\end{array}$ & $\begin{array}{l}(-0.008- \\
-0.000)\end{array}$ \\
\hline \multicolumn{7}{|c|}{ number of books in parent(s)' family homes when they were 10 (ref. <10 books) } \\
\hline \multirow{2}{*}{$11-25$ books } & & $0.083^{\star \star}$ & $0.075^{\star \star}$ & & $0.078 \star \star \star$ & $0.069 * \star$ \\
\hline & & $(0.015-0.151)$ & $(0.007-0.144)$ & & $(0.020-0.137)$ & $(0.011-0.127)$ \\
\hline \multirow{2}{*}{ 26-100 books } & & $0.127 \star \star \star$ & 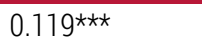 & & $0.124^{\star \star \star}$ & $0.116^{\star \star \star}$ \\
\hline & & $(0.060-0.195)$ & $(0.052-0.187)$ & & $(0.062-0.187)$ & $(0.054-0.179)$ \\
\hline \multirow{2}{*}{$101-200$ books } & & $0.190 \star \star \star$ & $0.181^{\star \star \star}$ & & $0.198^{\star \star \star}$ & 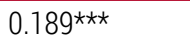 \\
\hline & & $(0.112-0.268)$ & $(0.102-0.259)$ & & $(0.120-0.276)$ & $(0.110-0.269)$ \\
\hline \multirow{2}{*}{ more than 200} & & $0.119 * \star$ & $0.111^{\star \star}$ & & $0.187^{\star \star \star}$ & $0.181^{\star \star \star}$ \\
\hline & & $(0.026-0.212)$ & $(0.017-0.204)$ & & $(0.094-0.279)$ & $(0.087-0.275)$ \\
\hline \multirow{2}{*}{$\begin{array}{l}\text { the importance of family } \\
\text { values ( } 0 \text { not important, } 1 \\
\text { important) }\end{array}$} & & & $0.081^{\star \star \star}$ & & & 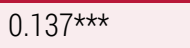 \\
\hline & & & $(0.026-0.136)$ & & & $(0.079-0.195)$ \\
\hline Observations & 6,579 & 6,129 & 6,129 & 6,689 & 6,144 & 6,144 \\
\hline
\end{tabular}

Confidence intervals (95\%) in parentheses, ${ }^{* * *} p<0.01,{ }^{* *} p<0.05,{ }^{*} p<0.1$.

Source: own estimations based on UDE data.

As a robustness check, we run a similar analysis using a more detailed, three-level scale of parenting intensity and an ordered logistic framework. The results (Table 6 in the Appendix) confirm the irrelevance of employment status for the incidence of educational activities with children and the crucial role of parents; human capital and values shared. The second robustness check comprised looking at household level parenting and labor markets status, instead of an individual perspective (Appendix table 7). The results were similar: non-working couples and non-working single parents are less likely to report high parenting intensity, compared to dual earners, both for the youngest and older children. At the same time there are no statistically significant differences in the parenting intensity between dual-earner parents and other couples in which at least one parent works, or working single parents.

Summing up, we find there is no link between parents' labour market status and his/her time spent with children on educational activities, as the relationship observed at an aggregated level is driven by parent's human capital. In the next section we focus on working parents only, to determine whether their parenting intensity is shaped by working time conditions. 


\subsection{Working time flexibility and parental time}

In the next step we deepen the analysis, hypothesizing that this is not the labour market status itself that matters for parenting intensity, but the characteristics of the job held, and whether it allows parents to spend more time with children. Thus, we are particularly interested in investigating the relationship between the level of parents' working time flexibility and their engagement in educational activities with children. To that end, we apply the approach of Eurofound in measuring the level of working time flexibility (described in detail in the Section 4). The distribution of working time flexibility index is plotted against the mean incidence of educational activities with children (in the household) aged 1-7 (left column) and 8-15 (right column) in the Figure 1. At the first glance, there is no clear pattern of association between those two variables, suggesting that mean parenting intensity does not depend on the level of parents' working time flexibility.

Fig. 1 Distribution of mean frequencies of educational activities with children 1-7 (left column) and 9-15 (right column) over the mean working time flexibility index with lowess smoothing
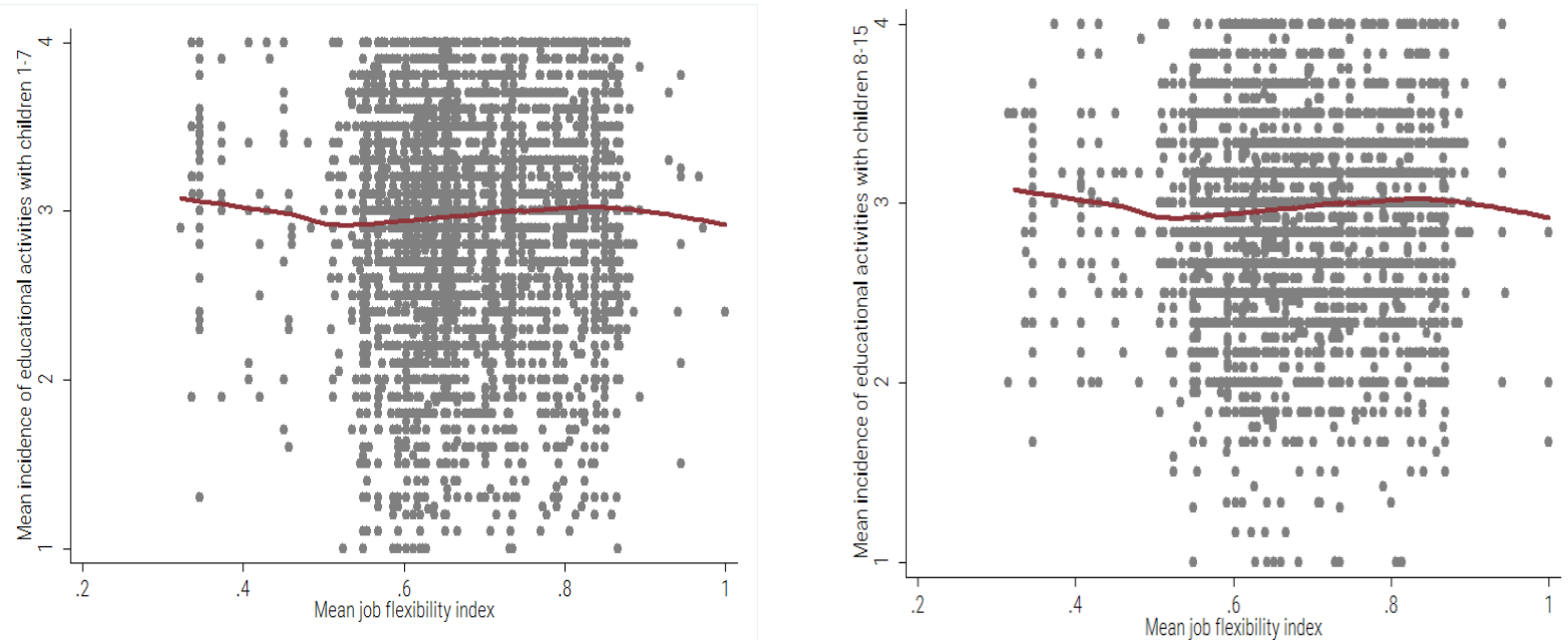

\section{Source: own elaboration based on UDE and EWCS data.}

To confirm this observation, we run a set of logit models similar to those presented in the Table 3 adding a new independent variable - the aggregated index of individual's working time flexibility. Likewise, the intended relationship between the overall index of working time flexibility and parental engagement in educational activities with children did not prove to be statistically significant (detailed results available upon request).

One might however assume that an aggregated index of working time flexibility, which captures both employerand employee- centered flexibility, blurs the picture. Those dimensions of working time flexibility that increase flexibility on the workers' side (e.g. taking an hour off from work) could increase parents' engagement in educational activities with children, whereas greater flexibility on the employers' side (e.g. the demand to come to work at short notice) is likely to suppress parents' engagement in educational activities with children. To verify whether it is indeed the case we add to the previous Model 3 from Table 3 a set of indicators measuring particular components of working time flexibility, as described in the methodology section (Section 4). We focus on working households only and present the marginal effects of intensive parenting probability for each working time flexibility item separately. Results are presented separately for younger and older children (Table 4). For the sake 
of clarity, estimated coefficients of other explanatory variables are not presented and are available from authors upon request.

Overall, none of the several measures of working time flexibility that we test appears to influence the time spent on educational activities with children. Estimated marginal effects are all statistically insignificant regardless of the age of children. However, three dimensions could be perceived as possibly significant for the parents' engagement in educational activities with children aged 1-7 (as their p-values are slightly above the threshold of 0.1). In particular, individuals who are characterized by the above-average incidence of working night shifts $(p=0.14)$ or working on Sundays ( $p=0.11$ ) also experienced lower probability of high-intensity parenting (by approx. 3pp.). Similarly, those who are frequently obliged to work at short notice might be less likely to engage in educational activities with their children (marginal effect of $-3 p p ., p=0.19$ ). Working night shifts and working at short notice also decrease the probability of high-intensity parenting among children aged 8-15 - in both cases the estimated marginal effects stand at $-2 p p$. with p-values equal to 0.26 and 0.27 , respectively. Compared to effects of other variables such as age or scholar culture of parents these marginal effects of working time flexibility dummies are, however, modest at best. Other dimensions of working time flexibility proved highly statistically insignificant with $p$-values ranging from 0.32 to 0.94 .

Table 4. Marginal effects of working time flexibility measures, all other explanatory variables at their means

\begin{tabular}{|c|l|l|l|l|l|l|l|l|l|l|}
\hline & $\begin{array}{c}\text { long } \\
\text { working } \\
\text { hours }\end{array}$ & $\begin{array}{c}\text { long } \\
\text { working } \\
\text { days }\end{array}$ & $\begin{array}{c}\text { night } \\
\text { work }\end{array}$ & $\begin{array}{c}\text { Saturday } \\
\text { work }\end{array}$ & $\begin{array}{l}\text { Sunday } \\
\text { work }\end{array}$ & $\begin{array}{l}\text { shift } \\
\text { work }\end{array}$ & scheduling & $\begin{array}{l}\text { short } \\
\text { notice }\end{array}$ & $\begin{array}{c}\text { hour } \\
\text { off }\end{array}$ & $\begin{array}{l}\text { work } \\
\text { free- } \\
\text { time }\end{array}$ \\
\hline $\begin{array}{c}\text { parenting, } \\
\text { children aged 1-7 } \\
\text { (0-low, 1-high) }\end{array}$ & 0.00 & 0.01 & -0.03 & 0.02 & -0.04 & 0.01 & 0.02 & -0.02 & -0.00 & 0.01 \\
\cline { 2 - 10 } & $\begin{array}{l}(-0.04- \\
0.04)\end{array}$ & $\begin{array}{l}(-0.03- \\
0.04)\end{array}$ & $\begin{array}{l}(-0.07- \\
0.01)\end{array}$ & $\begin{array}{l}(-0.02- \\
0.06)\end{array}$ & $\begin{array}{l}(-0.08- \\
0.01)\end{array}$ & $\begin{array}{l}(-0.03- \\
0.06)\end{array}$ & $\begin{array}{l}(-0.02- \\
0.06)\end{array}$ & $\begin{array}{l}(-0.07 \\
-0.02)\end{array}$ & $\begin{array}{l}(-0.04- \\
0.04)\end{array}$ & $\begin{array}{l}(-0.04- \\
0.05)\end{array}$ \\
\hline $\begin{array}{c}\text { parenting, } \\
\text { children aged 8-15 } \\
\text { (0-low, 1-high) }\end{array}$ & -0.00 & -0.00 & -0.03 & 0.02 & -0.00 & 0.00 & -0.01 & -0.02 & -0.01 & -0.02 \\
\cline { 2 - 10 } & $\begin{array}{l}(-0.05- \\
0.04)\end{array}$ & $\begin{array}{l}(-0.05- \\
0.04)\end{array}$ & $\begin{array}{l}(-0.07- \\
0.01)\end{array}$ & $\begin{array}{l}(-0.03- \\
0.06)\end{array}$ & $\begin{array}{l}(-0.05- \\
0.04)\end{array}$ & $\begin{array}{l}(-0.05- \\
0.05)\end{array}$ & $\begin{array}{l}(-0.06- \\
0.03)\end{array}$ & $\begin{array}{l}(-0.06 \\
-0.02)\end{array}$ & $\begin{array}{l}(-0.06- \\
0.03)\end{array}$ & $\begin{array}{l}(-0.06- \\
0.02)\end{array}$ \\
\hline
\end{tabular}

Source: own estimations based on UDE data. ${ }^{* *} p<0.01,{ }^{* *} p<0.05,{ }^{*} p<0.1$.

\section{Conclusions}

This paper adds to the literature on early childhood inequalities by shedding light on the factors influencing parental time investments into children. In particular, we focus our attention on investigating the role of parental socio-economic status and background, as measured by parental labor market position, educational attainment and values and attitudes parents share. We try to disentangle these from labour market limitations and possibilities stemming from job (in)flexibility.

Our main finding is that having more or less working time flexibility does not influence the amount of time working parents spend with their children on educational activities, despite our expectations that parents with more working time flexibility would be more likely to invest time into their children. It turns out that parenting intensity is shaped mostly by parent's human capital, socio-economic background and own childhood circumstances (as proxied by the number of books at home at the age of 10) and family values they share. 
We see two potential explanations for our main results of no link between working time flexibility and parenting intensity. Firstly, this finding actually confirms the biggest role played by the parental human capital and social status (parents' education and their socioeconomic background). Better educated parents, in particular those with tertiary education levels, are much more likely to find the time to spend on educational activities with their children, regardless of their time budget limitations related to labor market attachment and regardless of working time (in)flexibility. Second, it may be that the link between working time flexibility and parental time invested into children is more complex and that certain dimensions of working time flexibility are important, but we don't see them in our data. This might concern e.g. flexibility demands by the employers (e.g. on-call demands, the necessity to check emails and answer phone calls after the working day has officially ended) which we expect could lower time available for children. The close-to-significance p-values associated with working night shifts and on Sundays deserve further research attention, to establish whether these working arrangements do play a role for parental time spent with children, or whether there are other unobserved factors that should be considered.

\section{References}

Aizer, A., Cunha, F. (2012). The Production of Human Capital in Childhood: Endowments, Investments and Fertility. National Bureau of Economic Research Working Paper Series, (18429).

Amatea, E. S., Cross, G. E., Clark, and J. E., Bobby, C,L. (1986). Assessing the work and family role expectations of careeroriented men and women: The life role salience scales. Journal of Marriage and the Family, 48(4) 831-838.

Baxter, J. (2010). Parental time with children (Text no. 44). Australian Institute of Family Studies.

Bianchi, S. M. (2000). Maternal employment and time with children: dramatic change or surprising continuity? Demography, 37(4), 401-414. http://doi.org/10.1353/dem.2000.0001

Bidwell, M., Briscoe, F., Fernandez-Mateo, I., and Sterling, A. (2013). The employment relationship and inequality: How and why changes in employment practices are reshaping rewards in organizations. The Academy of Management Annals, $7(1), 61-121$.

Bohle, D., \& Greskovits, B. (2007). Neoliberalism, embedded neoliberalism and neocorporatism: Towards transnational capitalism in Central-Eastern Europe. West European Politics, 30(3), 443-466.

Bruins, M. (2017). Women's economic opportunities and the intra-household production of child human capital. Labour Economics.44, 122-132

Carneiro, P. and Ginja, R. (2015). Partial Insurance and Investments in Children. CEPR Discussion Papers

Carneiro, P., Meghir, C., and Parey, M. (2013). Maternal education, home environments, and the development of children and adolescents. Journal of the European Economic Association, 11(s1), 123-160.

Chiswick, B. R. (1988). Differences in education and earnings across racial and ethnic groups: Tastes, discrimination, and investments in child quality. The Quarterly Journal of Economics 103(3), 571-59

Cinamon, R. G. and Rich, Y. (2002). Profiles of attribution of importance to life roles and their implications for the work-family conflict. Journal of Counselling Psychology. 49, 212-220.

Craig, L., Powell, A. (2012). Dual-earner parents' work-family time: the effects of atypical work patterns and non-parental childcare. Journal of Population Research. 29, 229-247

Craig, L., Powell, A., Smyth, C. (2014). Towards intensive parenting? Changes in the composition and determinants of mothers' and fathers' time with children 1992-2006. The British Journal of Sociology, 65(3), 555-579. 
Dotti Sani, G. M. and Treas, J. (2016). Educational Gradients in Parents' Child-Care Time Across Countries, 1965-2012. Journal of Marriage and Family, 78(4), 1083-1096.

Eurofound (2016), Sixth European Working Conditions Survey - Overview report, Publications Office of the European Union, Luxembourg.

Evans, M. D., Kelley, J., Sikora, J. and Treiman, D. J. (2010). Family scholarly culture and educational success: Books and schooling in 27 nations. Research in social stratification and mobility, 28(2), 171-197.

Fergusson, D. M., Horwood, L. J. and Boden, J. M. (2008). The transmission of social inequality: Examination of the linkages between family socioeconomic status in childhood and educational achievement in young adulthood. Research in Social Stratification and Mobility, 26(3), 277-295.

Findlay, P., Kalleberg, A. L. and Warhurst, C. (2013). The challenge of job quality. Human Relations, 66(4), 441-451.

Fiorini, M. and Keane, M.P. (2014). How the allocation of children's time affects cognitive and noncognitive development. Journal of Labor Economics. 32 (4), 787-836.

Francesconi, M. and Heckman, J. J. (2016). Symposium on Child Development and Parental Investment : Introduction. IZA Discussion Paper, (9977).

Gayle, G., Golan and L., Soytas, M. (2015). What Accounts for the Racial Gap in Time Allocation and Intergenerational Transmission of Human Capital ? Federal Reserve Bank of St Louis.

Golden, L. (2001). Flexible work schedules: Which workers get them? American Behavioral Scientist, 44, 1157-1178.

Gornick, J. C., \& Meyers, M. K. (2003). Families that work: Policies for reconciling parenthood and employment. Russell Sage Foundation.

Haddock ,A. S., Zimmerman Schnidler, T., Ziemba, J. S. and Lyness, P. K. (2006) Practices of dual-earner couples successfully balancing work and family. Journal of Family and Economic Issues 27(2).

Hoherz, S. (2016). Parental work hours demands and 'quality time' with children. PAA Conference 2017, Chicago

Holman, D. (2013) Job types and job quality in Europe. Human Relations 66(4): 475-502.

Javornik, J. (2014). Measuring state de-familialism: Contesting post-socialist exceptionalism. Journal of European Social Policy, 24(3), 240-257.

Kalleberg, A. L., Reskin, B. F. and Hudson, K. (2000). Bad jobs in America: Standard and nonstandard employment relations and job quality in the United States. American Sociological Review, 65, 256-278. doi:10.2307/2657440

Kelly, E. L., Ammons, S., Chermack, K. and Moen, P. (2010). Gendered challenge, gendered response: Confronting the ideal worker norm in a white-collar organization. Gender and Society, 24, 281-303. doi:10.1177/0891243210372073

Kotowska, I., Jóźwiak J. and Matysiak, A. (2008). Poland: Fertility decline as a response to profound societal and labour market changes. Demographic Research .19(22), 795-854.

Lynch, K. and O'Riordan, C.(1998). Inequality In Higher Education: A Study Of Class Barriers. British Journal of Sociology of Education. 19: 445-478.

Matysiak, A.and Węziak-Białowolska, D. (2016) Country-Specific Conditions for Work and Family Reconcilation: An Attempt at Quantification. European Journal of Population, 32(4)

Monna, B, Gauthier, A. (2008). A Review of Literature on the Social and Economic Determinants of Parental Time. Journal of Family and Economic /ssues. 29(4), 634-53

Plomien, A. (2009) Welfare State, Gender, and Reconcilation of Work and Family in Poland: Policy Developments and Practice in a New EU Member. Social Policy \& Administration. 43(2), 136-151

Razzu G. , (2016) Gender Inequality in the Eastern European Labour Market: Twenty-five years of transition since the fall of communism, Routledge, forthcoming.

Roeters, A. (2013). Cross-national differences in the association between parental work hours and time with children in Europe: a multilevel analysis. Social indicators research, 110(2), 637-658. 
Saxonberg, S., \& Szelewa, D. (2007). The continuing legacy of the communist legacy? The development of family policies in Poland and the Czech Republic. Social Politics, 14(3), 351-379.

Sayer L., Bianchi S., and J. Robinson, (2004) "Are Parents Investing Less in Children? Trends in Mothers' and Fathers' Time with Children," American Journal of Sociology 110, no. 1: 1-43.

Sayer, L. C., Gauthier, A. H., \& Furstenberg, F. F., Jr. (2004). Educational differences in parents' time with children: Crossnational variations. Journal of Marriage and Family, 66, 1152-1169.

Van Doorn, M., Pop, I. and Wolbers, M. H. (2011). Intergenerational transmission of education across European countries and cohorts. European Societies, 13(1), 93-117.

Wößmann, Ludger (2003). Schooling Resources, Educational Institutions and Student Performance: The International Evidence. Oxford Bulletin of Economics and Statistics 65 (2): 117-170. 


\section{Appendix}

\section{A1. Working time flexibility measure}

Table 5. Description of working time flexibility indices

\begin{tabular}{|c|c|c|}
\hline Dimension & Items & Remarks \\
\hline \multirow[t]{2}{*}{ Duration } & Long working hours (48 hours or more a week) & 1 if never works long hours, 0 otherwise \\
\hline & Long working days (10 hours or more a day) & 1 if never works long days, 0 otherwise \\
\hline \multirow{4}{*}{$\begin{array}{l}\text { Atypical } \\
\text { working time }\end{array}$} & Night work & 1 if never works at night, 0 otherwise \\
\hline & Saturday work & 1 if never works on Saturday, 0 otherwise \\
\hline & Sunday work & 1 if never works on Sunday, 0 otherwise \\
\hline & $\begin{array}{l}\text { Shift work: daily split shift, permanent shift, } \\
\text { alternating/rotating shifts, other type of shift } \\
\text { work }\end{array}$ & $\begin{array}{l}1 \text { if never works shifts, } 0.66 \text { if works permanent shifts, } \\
0.33 \text { if works alternating shifts, and } 0 \text { if works daily } \\
\text { shifts }\end{array}$ \\
\hline \multirow{10}{*}{$\begin{array}{l}\text { Working time } \\
\text { arrangements }\end{array}$} & Set by the company & \multirow{9}{*}{$\begin{array}{l}1 \text { if working time arrangement is not set by the } \\
\text { company or set by the company but no changes in } \\
\text { arrangements occur, } 0.75 \text { if set by the company and } \\
\text { changes occur several weeks in advance, } 0.50 \text { if } \\
\text { several days in advance, } 0.25 \text { if the day before, } 0 \text { if on } \\
\text { the same day }\end{array}$} \\
\hline & Can choose between different schedules & \\
\hline & Can adapt working hours & \\
\hline & Entirely determined by self & \\
\hline & No regular change & \\
\hline & Change the same day & \\
\hline & Change the day before & \\
\hline & Change several days in advance & \\
\hline & Change several weeks in advance & \\
\hline & $\begin{array}{l}\text { Requested to come to work at short notice (at } \\
\text { least several times a month) }\end{array}$ & $\begin{array}{l}1 \text { if never asked to come to work at short notice, } 0 \\
\text { otherwise }\end{array}$ \\
\hline \multirow[t]{2}{*}{ Flexibility } & $\begin{array}{l}\text { Very or fairly easy to take an hour off during } \\
\text { working hours to take care of personal or } \\
\text { family matters }\end{array}$ & $\begin{array}{l}1 \text { if very or fairly easy to arrange to take an hour off } \\
\text { from work, } 0 \text { otherwise }\end{array}$ \\
\hline & $\begin{array}{l}\text { Work in free time to meet work demands } \\
\text { (several times a month) }\end{array}$ & 1 if never works free time, 0 otherwise \\
\hline
\end{tabular}

Source: Own elaboration based on Eurofound (2016). 


\section{A2. Ordered logit models}

Table 6. Ordered logit estimations (odds-ratios) for categorical parenting measure as a dependent variable (separately for two parenting measures) at the individual level

\begin{tabular}{|c|c|c|c|}
\hline & \multicolumn{2}{|c|}{ parenting, children aged 1-7 } & \multirow{2}{*}{$\begin{array}{c}\text { parenting, } \\
\text { children aged 8-15 } \\
1 \text { vs. } 2 \text { vs. } 3 \\
\end{array}$} \\
\hline & 1 vs. 2 & 2 vs. 3 & \\
\hline \multicolumn{4}{|l|}{ ref. employed: open-ended contract } \\
\hline \multirow{2}{*}{ employed: fixed-term contract } & 0.873 & 0.873 & 0.958 \\
\hline & $(0.694-1.097)$ & $(0.694-1.097)$ & $(0.744-1.234)$ \\
\hline \multirow{2}{*}{ unemployed } & 0.853 & 0.853 & 0.931 \\
\hline & $(0.683-1.065)$ & $(0.683-1.065)$ & $(0.739-1.173)$ \\
\hline \multirow{2}{*}{ inactive } & 0.865 & 0.865 & 1.035 \\
\hline & $(0.663-1.130)$ & $(0.663-1.130)$ & $(0.791-1.354)$ \\
\hline \multicolumn{4}{|l|}{ ref. primary education } \\
\hline \multirow{2}{*}{ basic vocational } & 1.31 & 1.31 & 1.025 \\
\hline & $(0.949-1.808)$ & $(0.949-1.808)$ & $(0.762-1.377)$ \\
\hline \multirow{2}{*}{ general secondary } & $1.776^{\star \star \star}$ & 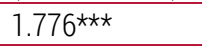 & 1.206 \\
\hline & $(1.229-2.569)$ & $(1.229-2.569)$ & $(0.839-1.736)$ \\
\hline \multirow{2}{*}{ vocational secondary and post-secondary } & $1.599 \star \star \star$ & $1.599 \star \star \star$ & 1.282 \\
\hline & $(1.146-2.231)$ & $(1.146-2.231)$ & $(0.932-1.764)$ \\
\hline \multirow{2}{*}{ tertiary } & $1.508^{\star \star}$ & $1.508^{\star \star}$ & $2.244 \star \star \star$ \\
\hline & $(1.074-2.117)$ & $(1.074-2.117)$ & $(1.572-3.204)$ \\
\hline \multicolumn{4}{|l|}{ ref. rural areas } \\
\hline \multirow{2}{*}{ town with less than $50 \mathrm{k}$ inhabitants } & 1.181 & 1.181 & 1.224 \\
\hline & $(0.923-1.511)$ & $(0.923-1.511)$ & $(0.956-1.566)$ \\
\hline \multirow{2}{*}{ town with $50 \mathrm{k}$ - $200 \mathrm{k}$ inhabitants } & 0.866 & 0.866 & 1.228 \\
\hline & $(0.655-1.145)$ & $(0.655-1.145)$ & $(0.930-1.622)$ \\
\hline \multirow{2}{*}{ town with more than $200 \mathrm{k}$ inhabitants } & $1.671^{\star \star}$ & 1.037 & $1.388^{\star \star}$ \\
\hline & $(1.076-2.595)$ & $(0.778-1.381)$ & $(1.020-1.889)$ \\
\hline \multirow{2}{*}{ children aged < 3 in the household ( 0 no, 1 yes) } & 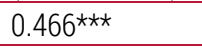 & 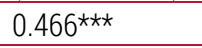 & 1.192 \\
\hline & $(0.382-0.568)$ & $(0.382-0.568)$ & $(0.889-1.598)$ \\
\hline \multirow{2}{*}{ number of children aged $>7$ in the household } & $0.817 \star \star \star$ & $0.817^{\star \star \star}$ & \\
\hline & $(0.709-0.941)$ & $(0.709-0.941)$ & \\
\hline \multirow{2}{*}{ age of parents } & 1.005 & 1.005 & $0.983^{\star \star}$ \\
\hline & $(0.988-1.022)$ & $(0.988-1.022)$ & $(0.967-0.999)$ \\
\hline \multicolumn{4}{|c|}{ number of books in parent(s)' family homes when they were 10 (ref. <10 books) } \\
\hline \multirow{2}{*}{$11-25$ books } & 1.229 & 1.229 & $1.325^{\star \star}$ \\
\hline & $(0.937-1.611)$ & $(0.937-1.611)$ & $(1.043-1.682)$ \\
\hline \multirow{2}{*}{$26-100$ books } & $1.492^{\star \star \star}$ & $1.492^{\star \star \star}$ & $1.601^{\star \star \star}$ \\
\hline & $(1.138-1.956)$ & $(1.138-1.956)$ & $(1.239-2.069)$ \\
\hline \multirow{2}{*}{$101-200$ books } & $1.938^{\star \star \star}$ & $1.938 * \star \star$ & $2.152^{\star \star \star}$ \\
\hline & $(1.386-2.709)$ & $(1.386-2.709)$ & $(1.549-2.990)$ \\
\hline \multirow{2}{*}{ more than 200} & $1.683^{\star \star \star}$ & $1.683^{\star \star \star}$ & $2.080 \star \star \star$ \\
\hline & $(1.170-2.420)$ & $(1.170-2.420)$ & $(1.413-3.061)$ \\
\hline \multirow{2}{*}{ the importance of family values } & $1.333^{\star \star \star}$ & $1.333^{\star \star \star}$ & $1.729 \star \star \star$ \\
\hline & $(1.076-1.652)$ & $(1.076-1.652)$ & $(1.372-2.180)$ \\
\hline \multirow{2}{*}{ Constant } & $4.641^{\star \star \star}$ & $0.540^{\star}$ & 0.566 \\
\hline & $(2.257-9.542)$ & $(0.265-1.100)$ & $(0.265-1.208)$ \\
\hline Observations & 6,129 & 6,129 & 6,144 \\
\hline
\end{tabular}

Confidence intervals (95\%) in parentheses, ${ }^{* * *} p<0.07,{ }^{* *} p<0.05, * p<0.1$

Note: The above estimations were derived using Stata and gologit2 function. Since some variables do not satisfy the proportional odds assumptions, separate models for levels 7 vs. 3 and 2 vs. 3 were estimated.

Source: Own calculations based on UDE data. 
Table 7. Ordered logit estimations (odds-ratios) for categorical parenting measure as a dependent variable (separately for two parenting measures) at the household level

\begin{tabular}{|c|c|c|c|c|}
\hline & \multicolumn{2}{|c|}{ parenting, children aged 1-7 } & \multicolumn{2}{|c|}{ parenting, children aged 8-15 } \\
\hline & 1 vs. 2 & 2 vs. 3 & 1 vs. 2 & 2 vs. 3 \\
\hline \multicolumn{5}{|l|}{ ref. dual-earner } \\
\hline \multirow{2}{*}{ dual non-earner } & 0.674 & 0.674 & 0.848 & 0.848 \\
\hline & $(0.361-1.258)$ & $(0.361-1.258)$ & $(0.460-1.564)$ & $(0.460-1.564)$ \\
\hline \multirow{2}{*}{ single earner } & 0.912 & 0.912 & 0.849 & 0.849 \\
\hline & $(0.636-1.308)$ & $(0.636-1.308)$ & $(0.572-1.260)$ & $(0.572-1.260)$ \\
\hline \multirow{2}{*}{ single not working } & 0.821 & 0.821 & 0.832 & 0.832 \\
\hline & $(0.507-1.330)$ & $(0.507-1.330)$ & $(0.452-1.531)$ & $(0.452-1.531)$ \\
\hline \multirow{2}{*}{ male breadwinner } & 1.052 & 1.052 & 1.247 & 1.247 \\
\hline & $(0.808-1.370)$ & $(0.808-1.370)$ & $(0.928-1.677)$ & $(0.928-1.677)$ \\
\hline \multirow{2}{*}{ female breadwinner } & 1.034 & 1.034 & 1.016 & 1.016 \\
\hline & $(0.593-1.802)$ & $(0.593-1.802)$ & $(0.665-1.552)$ & $(0.665-1.552)$ \\
\hline \multicolumn{5}{|l|}{ ref. primary education } \\
\hline \multirow{2}{*}{ basic vocational } & 1.544 & 1.544 & 1.513 & 1.513 \\
\hline & $(0.889-2.680)$ & $(0.889-2.680)$ & $(0.811-2.824)$ & $(0.811-2.824)$ \\
\hline \multirow{2}{*}{ general secondary } & $2.004^{\star \star}$ & $2.004^{\star \star}$ & $1.861^{\star}$ & $1.861^{\star}$ \\
\hline & $(1.145-3.509)$ & $(1.145-3.509)$ & $(0.992-3.493)$ & $(0.992-3.493)$ \\
\hline \multirow{2}{*}{ vocational secondary and post-secondary } & 1.595 & 1.595 & $1.953^{\star \star}$ & $1.953^{\star \star}$ \\
\hline & $(0.910-2.796)$ & $(0.910-2.796)$ & $(1.036-3.682)$ & $(1.036-3.682)$ \\
\hline \multirow{2}{*}{ tertiary } & $1.764^{*}$ & $1.764^{\star}$ & $3.345^{\star \star \star}$ & $3.345^{\star \star \star}$ \\
\hline & $(0.997-3.120)$ & $(0.997-3.120)$ & $(1.711-6.541)$ & $(1.711-6.541)$ \\
\hline \multicolumn{5}{|l|}{ ref. rural areas } \\
\hline \multirow{2}{*}{ town with less than $50 \mathrm{k}$ inhabitants } & 1.185 & 1.185 & 1.237 & 1.237 \\
\hline & $(0.902-1.556)$ & $(0.902-1.556)$ & $(0.920-1.663)$ & $(0.920-1.663)$ \\
\hline \multirow{2}{*}{ town with $50 \mathrm{k}$ - $200 \mathrm{k}$ inhabitants } & 0.848 & 0.848 & 1.045 & 1.045 \\
\hline & $(0.603-1.192)$ & $(0.603-1.192)$ & $(0.727-1.502)$ & $(0.727-1.502)$ \\
\hline \multirow{2}{*}{ town with more than $200 \mathrm{k}$ inhabitants } & 1.029 & 1.029 & 1.083 & 1.083 \\
\hline & $(0.747-1.417)$ & $(0.747-1.417)$ & $(0.776-1.512)$ & $(0.776-1.512)$ \\
\hline \multirow{2}{*}{ children aged < 3 in the household ( 0 no, 1 yes) } & $0.469 \star \star \star$ & $0.469 * \star \star$ & 1.105 & 1.105 \\
\hline & $(0.377-0.585)$ & $(0.377-0.585)$ & $(0.816-1.497)$ & $(0.816-1.497)$ \\
\hline \multirow{2}{*}{ number of children aged $>7$ in the household } & $0.834 * \star \star$ & 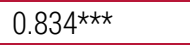 & & \\
\hline & $(0.737-0.945)$ & $(0.737-0.945)$ & & \\
\hline \multirow{2}{*}{ mean age of parents } & 0.991 & 0.991 & $0.981 *$ & $0.981 *$ \\
\hline & $(0.972-1.011)$ & $(0.972-1.011)$ & $(0.961-1.001)$ & $(0.961-1.001)$ \\
\hline \multicolumn{5}{|c|}{ number of books in parent(s)' family homes when they were 10 (ref. <10 books) } \\
\hline \multirow{2}{*}{$11-25$ books } & 1.275 & 1.275 & 1.038 & 1.038 \\
\hline & $(0.842-1.932)$ & $(0.842-1.932)$ & $(0.723-1.489)$ & $(0.723-1.489)$ \\
\hline $26-100$ hookc & $1.790 \star \star \star$ & $1.790 * \star \star$ & $1.474^{\star \star}$ & $1.474^{\star \star}$ \\
\hline 2b-100 DOOKS & $(1.169-2.740)$ & $(1.169-2.740)$ & $(1.018-2.134)$ & $(1.018-2.134)$ \\
\hline & $2.294^{\star \star \star}$ & $2.294^{\star \star \star}$ & $2.267 \star \star \star$ & $2.267 \star \star \star$ \\
\hline 101-200 DOOKS & $(1.404-3.747)$ & $(1.404-3.747)$ & $(1.443-3.562)$ & $(1.443-3.562)$ \\
\hline & $2.482^{\star \star \star}$ & $2.482^{\star \star \star}$ & $2.620 * * \star$ & $2.620 * \star \star$ \\
\hline more than 200 & $(1.465-4.206)$ & $(1.465-4.206)$ & $(1.453-4.722)$ & $(1.453-4.722)$ \\
\hline the imnertance of family yluec & $1.951^{\star \star \star}$ & $1.951^{\star \star \star}$ & $2.363^{\star \star \star}$ & $2.363^{\star \star \star}$ \\
\hline the importance of raminy values & $(1.306-2.915)$ & $(1.306-2.915)$ & $(1.499-3.724)$ & $(1.499-3.724)$ \\
\hline Conctant & $4.044^{\star \star \star}$ & $0.402^{\star}$ & $5.398 * \star \star$ & $0.164^{\star \star \star}$ \\
\hline constant & $(1.492-10.960)$ & $(0.148-1.090)$ & $(1.771-16.458)$ & $(0.053-0.505)$ \\
\hline Observations & 3,576 & 3,576 & 3,818 & 3818 \\
\hline
\end{tabular}

Confidence intervals (95\%) in parentheses, *** $p<0.01$, ** $p<0.05, * p<0.1$ Note: The above estimations were derived using Stata and gologit2 function. Since some variables do not satisfy the proportional odds assumptions, separate models for levels 7 vs. 3 and 2 vs. 3 were estimated. All variables are averaged at the household level (for adult individuals).

Source: own estimations based on UDE data. 
- $19 @ \begin{aligned} & \text { instytut } \\ & \text { badań } \\ & \text { strukturalnych }\end{aligned}$

www.ibs.org.pl 